\title{
BIODIVERSITY CONSERVATION OF NATIONAL PARKS AND NATURE-PROTECTED AREAS IN WEST AFRICA: THE CASE OF KAINJI NATIONAL PARK, NIGERIA
}

\author{
Adesina John ${ }^{1, *}$ and Tang Xiaolan ${ }^{1,2}$ \\ 1 College of Landscape Architecture, Nanjing Forestry University, Nanjing, 210037, China; adesina- \\ johnlloyd@gmail.com \\ 2 NFU Academy of Chinese Ecological Progress and Forestry Studies, Nanjing, 210037, China; \\ xiaolant@njfu.edu.cn \\ * Correspondence: adesinajohnlloyd@gmail.com,
}

\begin{abstract}
Due to rising global warming and climate change, biodiversity protection has become a critical ecological concern. The rich biodiversity zones are under threat and are deteriorating, necessitating national, regional, and provincial efforts to safeguard these natural areas. The effective conservation of National Parks and Nature-protected Areas helps to improve biodiversity conservations, forest, and urban air quality. The continuous encroachment and abuse of these protected areas have degraded the ecosystem over time. While exploring the geophysical ecology and biodiversity conservation of these areas in West Africa, Kainji National Park was selected for this study because of its notable location, naturalness, rich habitat diversity, topographic uniqueness, and landmass. The conservation of national parks and nature-protected areas is a cornerstone of biodiversity conservation globally. This study is aimed at the target of United Nations Sustainable Development Goal 13, 2030- Climate Action, targeted at taking urgent action towards combating climate change and its impacts. The study captures both flora and fauna that are dominant in the study area. The 15 identified trees were randomly sampled within a stratum of $10 \times 10 \mathrm{~km}$ shared into 24 plots for proper analyses using i-Tree Eco v6.0.23 software. The following data were captured and analyzed; Photosynthetically Active Radiation, Rain/Precipitation, Temperature, Transpiration, Evaporation, Water Intercepted by trees, Avoided Runoff by trees, Potential Evaporation by trees, Isoprene and Monoterpene by trees. This study also further discusses the tree benefits of green, low carbon, and sustainable environment within the context of biodiversity conservation considering carbon storage, carbon sequestration, hydrology effects, pollution removal, oxygen production, and volatile organic compounds (VOCs). There is a quick need for remotely-sensed information of the protected areas at regular intervals and government policies must be strict against illegal poaching and logging activities.
\end{abstract}

Keywords: Biodiversity Conservation; Carbon Storage \& Sequestration; Climate Change; Kainji National Park; Protected Areas.

\section{Introduction}

Biological richness is considered as "the variability among living species from all sources, including terrestrial, marine, and other aquatic habitats, as well as the ecological complexes of which they are a part" [1]. The convention's main goals are to conserve biodiversity, ensure the long-term viability of biodiversity components, and ensure equality in the allocation of genetic natural resources. Natural resources, public benefits, and environmental drivers of change are three components of biodiversity protection defined by the United States Environmental Protection Agency [2], as depicted in Figure 1. In this context, the Federal Ministry of Environment is taking a huge step toward accomplishing wildlife protection in Nigeria's national parks and protected regions, which is in line with the United Nations' Sustainable Development Goals 2030. 
Most nature reserves are places set aside and managed for wildlife and natural resource conservation. They are diversely rich in flora and animals in great numbers, and they all assist the ecology in some way [3].

Each West African country's government has institutions responsible for monitoring, patrolling, and controlling illegal poaching operations in these protected areas, as well as enforcing applicable international treaties and conventions to which all West African nations are signatories. Protecting life support systems such as watersheds and water catchment regions is one of the advantages of protected areas and national parks.

Due to the obvious significant potential for research development, most research institutions in agriculture, health, and bioorganic technology are located near or in some of these locations. The link between national security and national parks (protected areas) is one of the government's concerns [4]. National parks and protected regions are vital to every country's national security [5]. Unfortunately, the majority of state-owned forest reserves have now become hotbeds of criminal activity [6].

As a result, the formation of these national parks would offer the much-needed apparatus to fend off criminal elements in the country's present struggle against insurgency and other organized crimes such as poaching, cattle rustling, and illegal logging, amongst others.

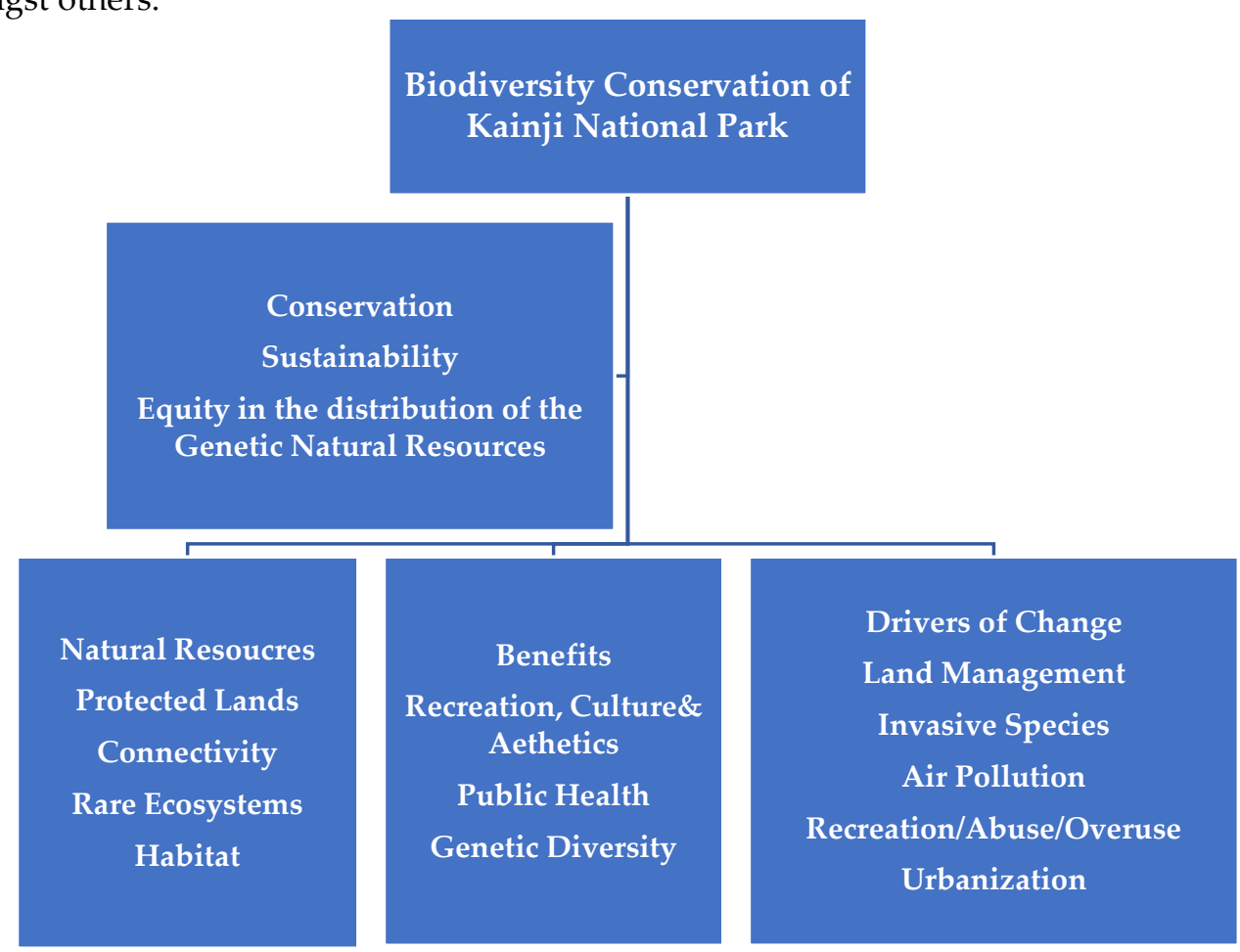

Figure 1. The objectives and key components of Biodiversity Conservation.

The existing approach to natural resource management by most states and municipal governments has outgrown the magnitude of strain on natural resources. Extension services on forestry and biodiversity-related issues have been ineffective in most West African nations, particularly Nigeria, leaving natural resource governance in shambles.

\section{Literature Review: Biodiversity, Protected Areas and National Parks}

According to Conservation International [1], the value of biodiversity in West Africa is well understood. The West African forest environment is also home to two of Africa's great apes, including a tiny population of western lowland gorillas near the Nige- 
ria-Cameroon border and remnant dispersed groups of endangered western chimpanzees [1]. A population of about 7,500 African elephants lives in West African countries, yet many of them live in northern savannah environments outside of forest ecosystems [7]. The Upper Guinean forest ecosystem in West Africa, on the other hand, is one of the world's most critically fragmented ecosystems [8].

The International Union for Conservation of Nature (IUCN) classified the Kainji National Park as a National Park in the second category II [9-11, 24]. In terms of size and primary goal of safeguarding functioning ecosystems, the National Park is comparable to a wilderness region. National parks, on the other hand, are more tolerant of human visitation and the infrastructure that supports it. National parks are administered in such a way that they may help local economies by fostering educational and recreational tourism at a scale that does not jeopardize conservation efforts [2, 12-13]. The significant sections of a national park may be used for recreational or non-recreational purposes, but they should nevertheless operate as a shield for the protection of the protected area's native(indigenous) species and communities so that they can thrive in the long run. In a system devised by the organization, IUCN protected area management categories are used to classify national parks and nature-protected areas [14]. The Aichi Targets "Living in Harmony with Nature" and the UN Decade of Biodiversity's Strategic Plan for Biodiversity 2011-2020 were examined in this study.

Biological variety, according to $[15,16]$, underlies ecosystem functioning and the provision of ecosystem services critical to human well-being. It ensures food security, human health, and access to clean air and water; it supports local livelihoods and economic growth, and it is critical to achieving the goals. It's also a big part of a lot of people's belief systems, worldviews, and identities. Biodiversity, despite its critical value, continues to be lost. In 2010, the Parties to the Convention on Biological Diversity approved the Strategic Plan for Biodiversity 2011-2020 in Nagoya, Japan, to encourage broad-based action in support of biodiversity by all governments and stakeholders during the following decade [17-19]. The United Nations General Assembly has also named 2011-2020 as the United Nations Decade on Biodiversity, recognizing the urgent need for action. The Biodiversity Strategic Plan 2011-2020 is a ten-year framework for action by all governments and partners to conserve biodiversity and maximize its benefits to people [20-23].

\subsection{The Study Area: Kainji National Park, Nigeria (West Africa)}

Located in both Kwara and Niger Provincial States of Nigeria, the Kainji National Park was given recognition in 1978, covering a land area of 5,341 $\mathrm{km}^{2}[21,22]$. There are 18 national parks and nature-protected areas in Nigeria, the first eight are already recognized while the remaining ten are yet to be given national recognition. It is divided into three distinct zones/sectors: the Kainji Lake, at the western area of the lake, is the Borgu Game Reserve, not too far from the South-east is the Zugurma Game Reserve. The Nigerian government through her agency known as the Federal National Park Service (FNPS) and there is a second agency known as the Nigeria National Park Service (NNPS). These two agencies manage and fund the park while preserving, enhancing, protecting, and managing vegetation and wild animals in the national parks, shortly after the Federal Government gave it special recognition in 2005. It was then considered as a Lion Conservation Unit[21-23]. There are laws and policies already in place that are been enforced and actions were taken against poaching and unscrupulous human activities which can be pursued under national park law. In line with the geographical location of the study site, there is mostly savanna forest which comprises majorly the Borgu Game Reserve has a land area of $3,929 \mathrm{~km}^{2}$, the least in terms of size amongst the game reserves is the while the Zugurma Game Reserve with a size of $1,370 \mathrm{~km}^{2}$. A $136 \mathrm{~km}$ long lake separating the two main parts of the park is the Kainji Lake (see Figure 2). The tourism sector under the 
Nigerian Tourism Development Corporation in this park is very limited because the location is just evolving into an urban settlement.

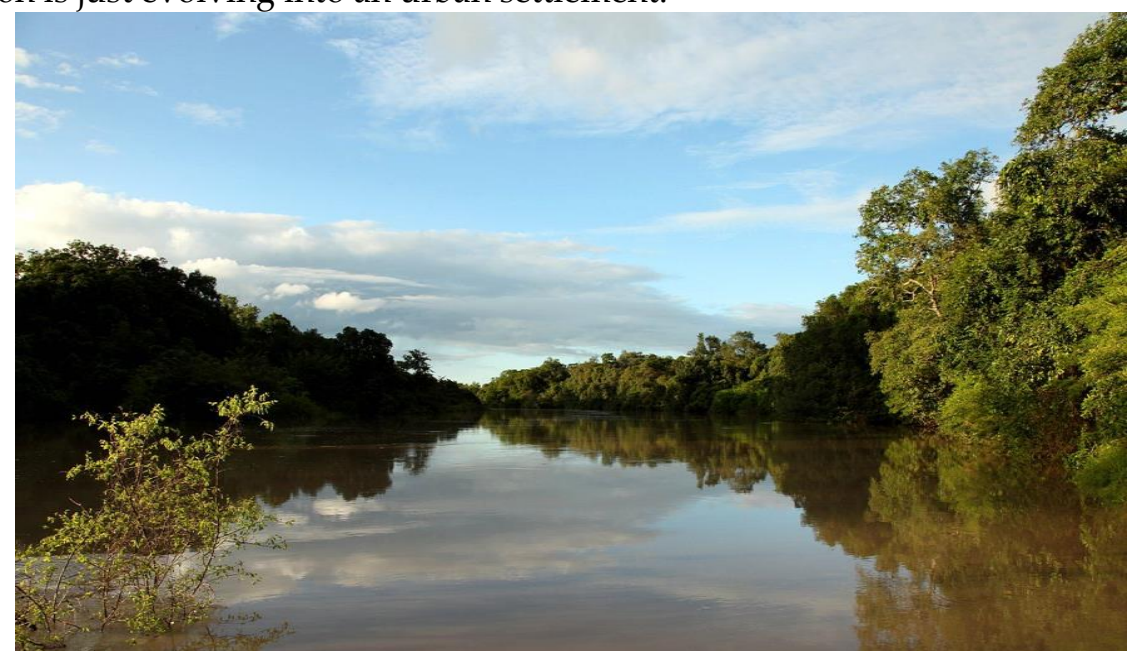

Figure 2. Kainji Lake, Lake in Kainji National Park (Photo Credit: Jeremy Weate, 2015).

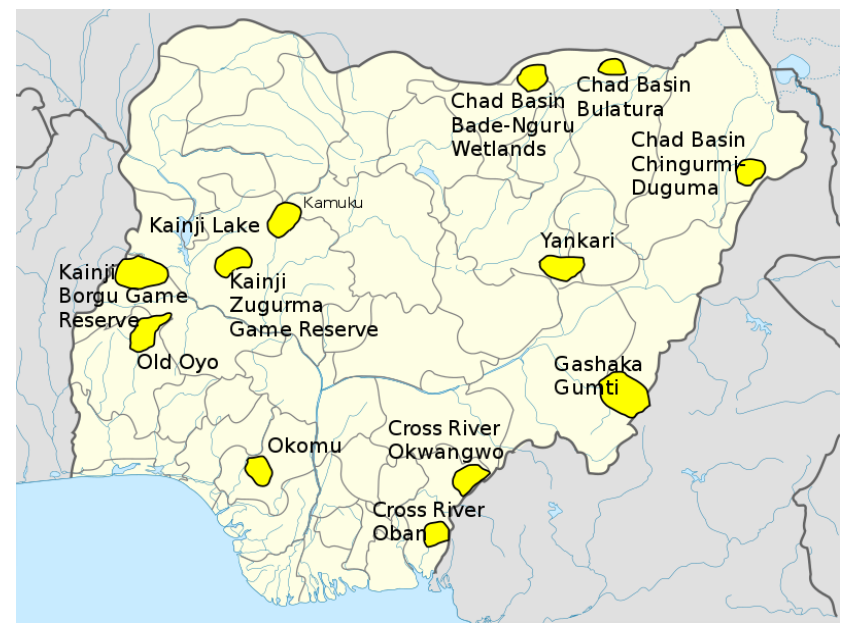

(a)

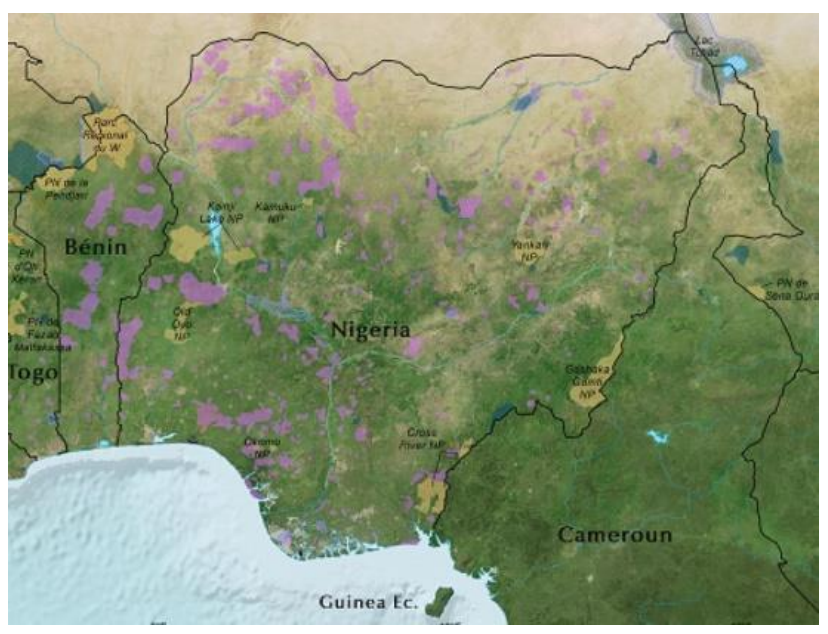

(b)

Figure 3. (a) Map showing the 8 recognized National Parks of Nigeria. (b) Map of Nigeria showing neighbouring West African Countries Biodiversity and Protected Areas in Nigeria $[9,24]$

\section{Methods: The Study Area Protocol}

Four remotely sensed imageries were used for assessment of the perpetual land-use changes that occurred in the past five decades The four Landsat imageries gotten from 1972, 1986, 2015, and 2021 show the dramatic transformation in the area surrounding these protected areas.

The transformation witnessed by the study area in the past five decades is enormous. The green area is gradually shifting from the wooded savanna into farmland and into the brown patches which are the present human settlements (see Figures 4,5,6 \& 7). 


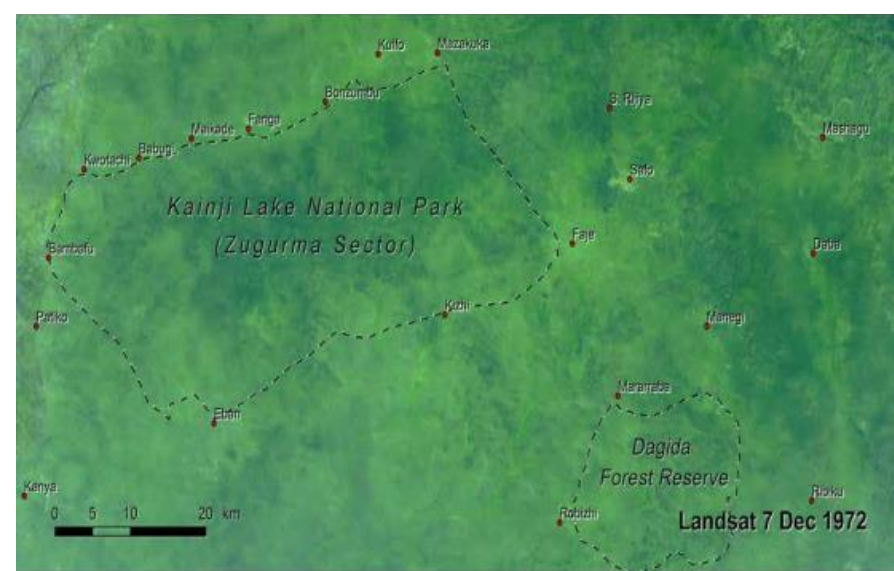

(a)

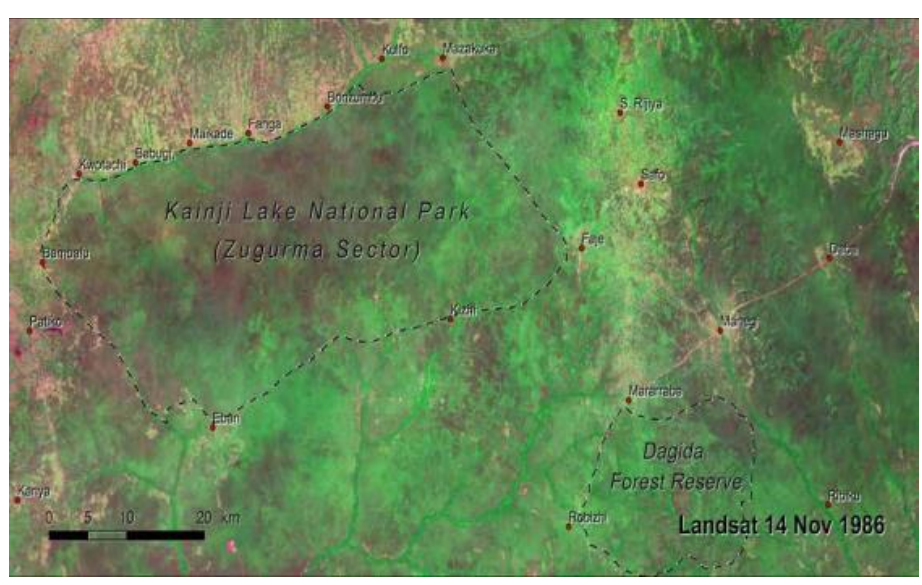

(b)

Figure 4. (a) Landsat Imageries of Kainji Lake National Park, 1972. (b) Landsat Imageries of Kainji Lake National Park, 1986.

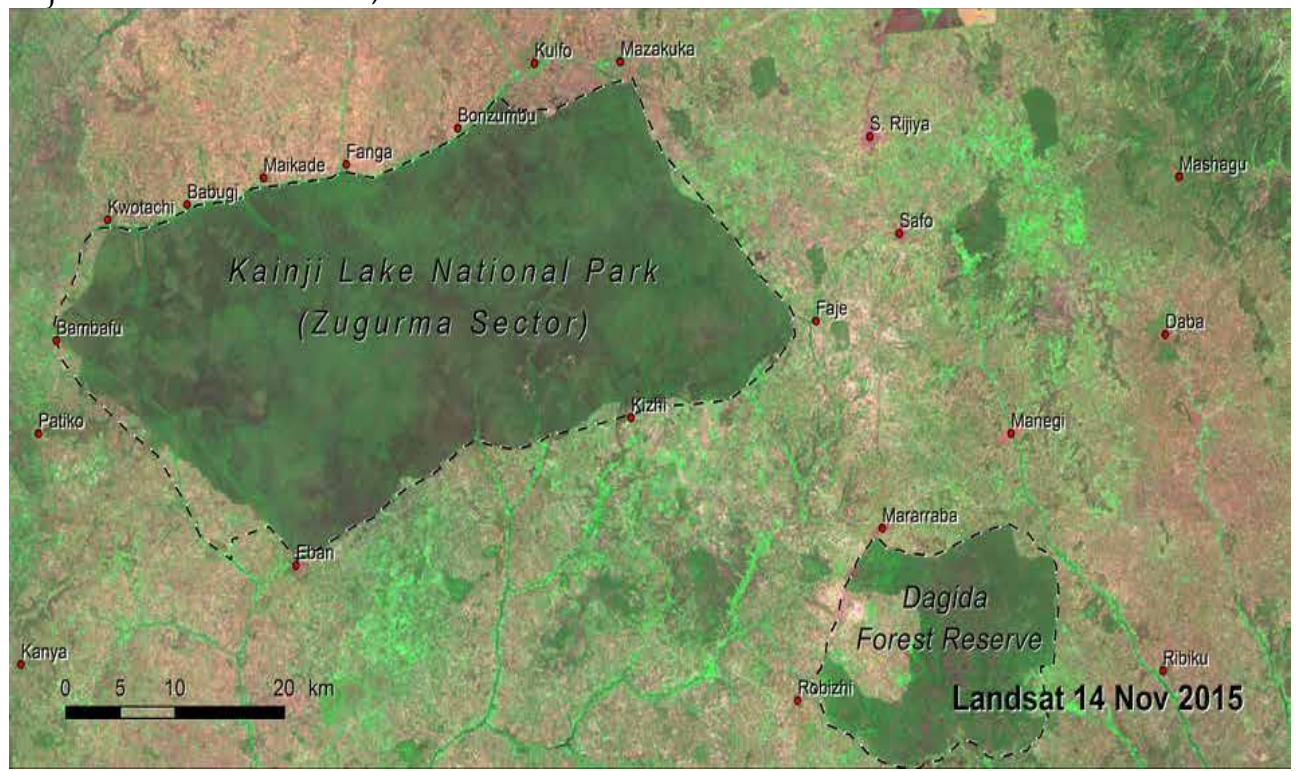

Figure 5. Landsat Imageries of Kainji Lake National Park, 2015.

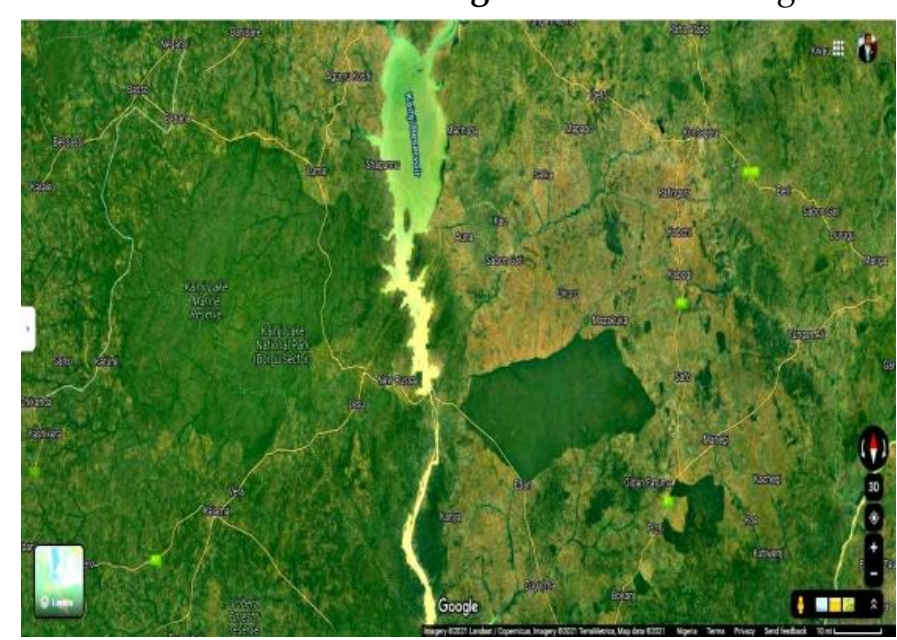

(a)

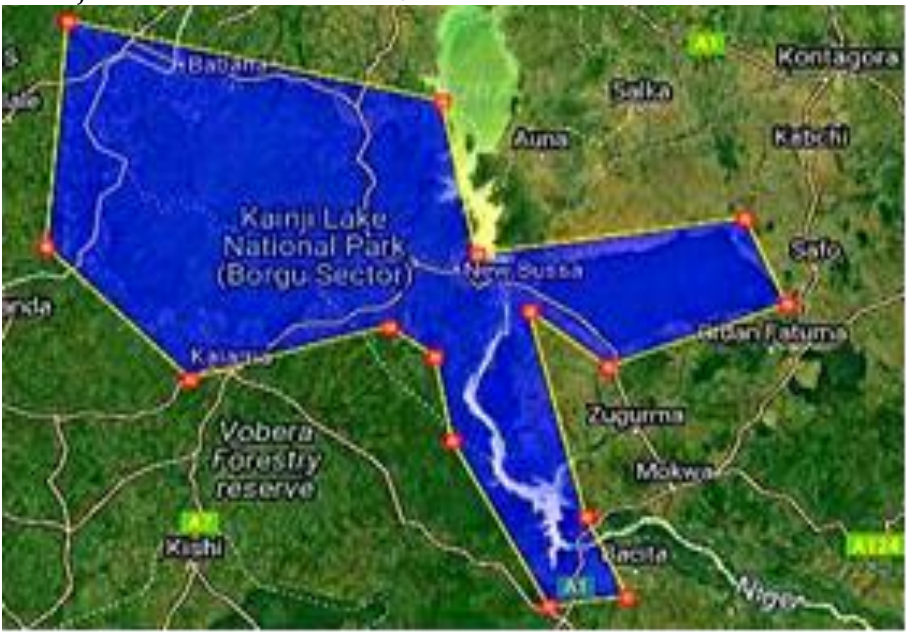

(b)

Figure 6. (a) Landsat Imageries of Kainji Lake National Park (showing the three zonesZugurma, Borgu, and Lake Kainji Zones). (b) Map showing the Study Area.

The rapid expansion of agriculture in this formerly semi-natural area can be understood in the context of changing land use and continuous agricultural purpose which has increased the Nigerian economy by the increase in food production, wood, and non-wood forest products. 


\subsection{Data Collection}

A random sampling strategy, consisting of a random sample of 10kilometre by 10kilometre $(10 \times 10 \mathrm{Km} 2)$ frames stratified stratum and all these strati are situated in a common ecoregion. These ecological areas have similar biophysical and environmental situations. This helps to ascertain the framework for effective research, inventory, and management of natural resources. A total of $5,341 \mathrm{~km}^{2}$ which is the total area of the park, a total of 24 frames were gotten and each frame was assessed based on the predominant flora and fauna that are present as shown in the tables below.

The dominant Flora is the savanna woodland of the Borgu sector is dominated by the following indigenous trees: Burkea Africana, Terminalia Avicennioides, Detarium Microcarpum. Isoberlinia Tomentosa, Diospyros Mespiliformis, Polysphaeria Orbuscula, Terminalia Macroptera, Isoberlinia Doka, Afzelia Africana, Daniella Oliveri, Pterocarpus Erinaceus, Parkia Clappertoniana, Vitellaria Paradoxa, Detarium Microcarpum, Uapaca Togoensis, all these indigenous trees belong to the following species of trees: Abies, Abelia, Dovyalis abyssinica Abarema Abies balsamea Acacia adunca Lagarostrobos franklinii Adenostoma Adenaria floribunda Salix fragilis Hakea francisiana Acacia argyrophylla Adenaria floribunda Carya x schneckii Adenostoma fasciculatum as used in the i-Tree Eco v6.0.23. Dominant Geographical Zones are Zugurma Zone Borgu Zone and Lake Kainji.

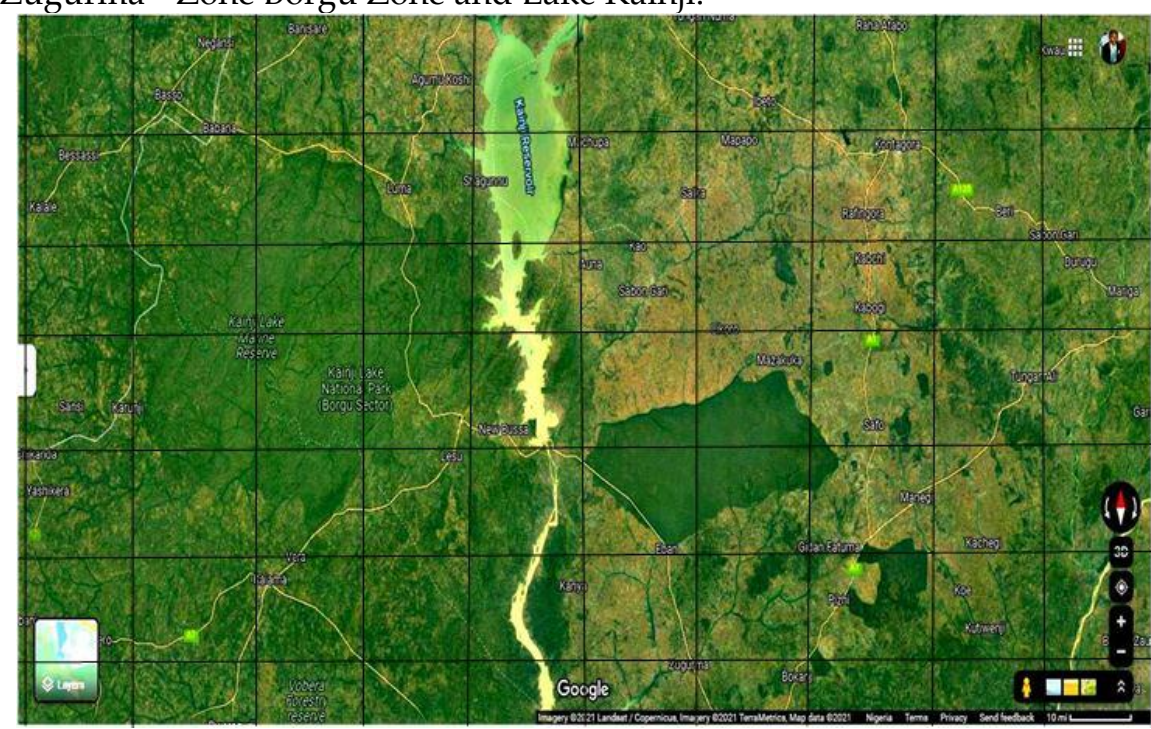

Figure 7. Framing the Study Area.

The dominant fauna is over 70 mammal species, over 400 species of birds, and 40 species of reptiles and amphibians have been recorded in the park. These include the following wildlife: Elephant, African Manatee, Antelope, Hippopotamus, African Wild Dog, Honey Badger, Senegal Bushbaby, Monkey, African Clawless Otter. There are lots of Reptiles like Nile Crocodile, West African Slender-Snouted Crocodile, Turtle Species, Nile Monitor, Savannah Monitor, Lizards, Snakes, Baboons, Duikers, Hyenas, Roan Antelopes. Numerous species of Amphibians (15 amphibian species) were spotted, Fish (90 species- numerous species) the reptiles, amphibians, and fish are commonly spotted at the Lake Kainji zone. Assessing the form, function, and value of an urban forest may help guide management decisions that benefit human health and the environment.

During the year 2021, a study of the vegetation structure, function, and value of Kainji National Park and the protected forest was carried out. The i-Tree Eco model created by the US Forest Service's Northern Research Station was used to evaluate data through multiple frames of one plot placed throughout the research region with the assistance of the nearest weather station. 
The following tables give the reports of individual-level results composition and structure of trees in the study area according to the weather station close to the location (see Table 1 \& 2 for the weather station data). The existing Flora and Fauna were identified and the i-Tree Eco v6.0.23 was used for onward analysis using the following parameters.

Table 1 presents a summary of the data collected in the field as well as additional estimated tree characteristics for each of the trees sampled. This table includes Plot and Tree ID, Species Name, DBH, Height, Street Tree Status, and estimates for the following: Canopy Cover, Tree Condition, Leaf Area, Leaf Biomass, Leaf Area Index - estimated by dividing Leaf Area by Canopy Cover, and Basal Area. Tree condition categories are defined as follows:

a. Crown Health (dieback): Excellent = 0\% dieback, Good = $1-10 \%$ dieback, Fair $=10-$ $25 \%$ dieback, Poor $=25-50 \%$ dieback, Critical $=50-75 \%$ dieback, Dying $=75-99 \%$ dieback, Dead $=100 \%$ dieback.

b. Crown Health (condition): Excellent $=100 \%$ condition, Good $=90-99 \%$ condition, Fair $=75-90 \%$ condition, Poor $=50-75 \%$ condition, Critical $=25-50 \%$ condition, Dying $=1-25 \%$ condition, Dead $=0 \%$ condition.

Table 1. Composition and Structure of Individual Trees.

Composition and Structure of Individual Trees

Location: Ado-Ekiti, Ekiti, Nigeria

Project: BIODIVERSITY CONSERVATION OF KAINJI PARK, Series: NJFU PAPER, Year: 2021

Generated: 10/10/2021

\begin{tabular}{|c|c|c|c|c|c|c|c|c|c|c|c|c|c|}
\hline Plot ID & Tree ID & Species Name & $\begin{array}{l}\text { DBH } \\
(\mathrm{cm})\end{array}$ & $\begin{array}{r}\text { Height } \\
(\mathrm{m})\end{array}$ & $\begin{array}{r}\text { Crown Height } \\
(\mathrm{m})\end{array}$ & $\begin{array}{r}\text { Crown Width } \\
(\mathrm{m})\end{array}$ & $\begin{array}{r}\text { Canopy Cover } \\
\left(\mathrm{m}^{2}\right) \\
\end{array}$ & Tree Condition & $\begin{array}{r}\text { Leaf Area } \\
\left(\mathrm{m}^{2}\right)\end{array}$ & $\begin{array}{r}\text { Leaf Biomass } \\
(\mathrm{kg}) \\
\end{array}$ & Leaf Area Index & $\begin{array}{r}\text { Basal Area } \\
\left(\mathrm{m}^{2}\right) \\
\end{array}$ & Native to State \\
\hline 1 & 1 & Abies & 35.0 & 30.0 & 10.0 & 15.0 & 176.7 & CRITICAL & 558.1 & 78.6 & 3.2 & 0.1 & \\
\hline 1 & 2 & Abelia & 35.4 & 20.0 & 9.0 & 8.0 & 50.3 & POOR & 334.1 & 17.5 & 6.6 & 0.1 & \\
\hline 1 & 3 & Dovyalis abyssinica & 35.0 & 60.0 & 10.0 & 20.0 & 314.2 & CRITICAL & 728.9 & 62.3 & 2.3 & 0.1 & \\
\hline 1 & 4 & Abarema & 35.0 & 35.0 & 10.0 & 17.5 & 240.5 & CRITICAL & 171.8 & 14.8 & 0.7 & 0.1 & \\
\hline 1 & 5 & Abies balsamea & 50.0 & 30.0 & 2.0 & 15.0 & 176.7 & CRITICAL & 209.1 & 21.8 & 1.2 & 0.2 & \\
\hline 1 & 6 & Acacia adunca & 50.0 & 20.0 & 3.0 & 12.5 & 122.7 & CRITICAL & 11.6 & 2.8 & 0.1 & 0.2 & \\
\hline 1 & 7 & Lagarostrobos franklinii & 15.0 & 30.0 & 6.0 & 12.5 & 122.7 & POOR & 11.5 & 1.4 & 0.1 & 0.0 & \\
\hline 1 & 8 & Adenostoma & 40.0 & 65.0 & 10.0 & 12.5 & 122.7 & CRITICAL & 187.5 & 14.1 & 1.5 & 0.1 & \\
\hline 1 & 9 & Adenaria floribunda & 25.0 & 30.0 & 11.0 & 17.5 & 240.5 & CRITICAL & 60.2 & 7.8 & 0.3 & 0.0 & \\
\hline 1 & 10 & Salix fragilis & 10.0 & 25.0 & 1.0 & 12.5 & 122.7 & CRITICAL & 5.5 & 0.3 & 0.0 & 0.0 & \\
\hline 1 & 11 & Hakea francisiana & 20.0 & 20.0 & 2.0 & 12.5 & 122.7 & CRITICAL & 73.6 & 9.0 & 0.6 & 0.0 & \\
\hline 1 & 12 & Acacia argyrophylla & 40.0 & 35.0 & 12.0 & 17.0 & 227.0 & CRITICAL & 43.6 & 10.5 & 0.2 & 0.1 & \\
\hline 1 & 13 & Adenaria floribunda & 50.0 & 40.0 & 15.0 & 25.0 & 490.9 & DYING & 36.3 & 4.7 & 0.1 & 0.2 & \\
\hline 1 & 14 & Carya x schneckii & 28.0 & 30.0 & 10.0 & 16.5 & 213.8 & CRITICAL & 89.4 & 6.0 & 0.4 & 0.1 & \\
\hline 1 & 15 & Adenostoma fasciculatum & 45.0 & 35.0 & 5.0 & 10.0 & 78.5 & DYING & 177.2 & 13.3 & 2.3 & 0.2 & \\
\hline & & Total & & & & & $2,822.7$ & & $2,698.6$ & 265.0 & & 1.6 & \\
\hline
\end{tabular}

Table 2 presents a summary of the data collected in the field as well as additional estimated tree characteristics for each of the trees sampled. This table includes estimates for the following characteristics: Tree Count, Canopy Cover, Leaf Area, Leaf Biomass, and Basal Area. 
Table 2. Composition of Individual Trees by Species.

Composition and Structure of Individual Trees by Species

Location: Ado-Ekiti, Ekiti, Nigeria Generated: 10/10/2021

\begin{tabular}{|c|c|c|c|c|c|c|c|c|c|c|}
\hline \multirow[t]{2}{*}{ Species Name } & \multicolumn{2}{|c|}{ Tree Count } & \multicolumn{2}{|c|}{ Canopy Cover $\left(\mathrm{m}^{2}\right)$} & \multicolumn{2}{|c|}{ Leaf Area $\left(\mathrm{m}^{2}\right)$} & \multicolumn{2}{|c|}{ Leaf Biomass (kg) } & \multicolumn{2}{|c|}{ Basal Area $\left(\mathrm{m}^{2}\right)$} \\
\hline & Value & $\%$ & Value & $\%$ & Value & $\%$ & Value & $\%$ & Value & $\%$ \\
\hline Abarema & 1 & 6.7 & 240.5 & $\overline{8.5}$ & 171.8 & 6.4 & 14.8 & 5.6 & 0.1 & 6.2 \\
\hline Abelia & 1 & 6.7 & 50.3 & 1.8 & 334.1 & 12.4 & 17.5 & 6.6 & 0.1 & 6.3 \\
\hline Abies & 1 & 6.7 & 176.7 & 6.3 & 558.1 & 20.7 & 78.6 & 29.7 & 0.1 & 6.2 \\
\hline Abies balsamea & 1 & 6.7 & 176.7 & 6.3 & 209.1 & 7.7 & 21.8 & 8.2 & 0.2 & 12.6 \\
\hline Acacia adunca & 1 & 6.7 & 122.7 & 4.3 & 11.6 & 0.4 & 2.8 & 1.1 & 0.2 & 12.6 \\
\hline Acacia argyrophylla & 1 & 6.7 & 227.0 & 8.0 & 43.6 & 1.6 & 10.5 & 4.0 & 0.1 & 8.1 \\
\hline Adenaria floribunda & 2 & 13.3 & 731.4 & 25.9 & 96.5 & 3.6 & 12.5 & 4.7 & 0.2 & 15.8 \\
\hline Adenostoma & 1 & 6.7 & 122.7 & 4.3 & 187.5 & 6.9 & 14.1 & 5.3 & 0.1 & 8.1 \\
\hline Adenostoma fasciculatum & 1 & 6.7 & 78.5 & 2.8 & 177.2 & 6.6 & 13.3 & 5.0 & 0.2 & 10.2 \\
\hline Carya x schneckii & 1 & 6.7 & 213.8 & 7.6 & 89.4 & 3.3 & 6.0 & 2.3 & 0.1 & 4.0 \\
\hline Dovyalis abyssinica & 1 & 6.7 & 314.2 & 11.1 & 728.9 & 27.0 & 62.3 & 23.5 & 0.1 & 6.2 \\
\hline Hakea francisiana & 1 & 6.7 & 122.7 & 4.3 & 73.6 & 2.7 & 9.0 & 3.4 & $<0.1$ & 2.0 \\
\hline Lagarostrobos franklinii & 1 & 6.7 & 122.7 & 4.3 & 11.5 & 0.4 & 1.4 & 0.5 & $<0.1$ & 1.1 \\
\hline Salix fragilis & 1 & 6.7 & 122.7 & 4.3 & 5.5 & 0.2 & 0.3 & 0.1 & $<0.1$ & 0.5 \\
\hline Total & 15 & 100 & $2,822.7$ & 100 & $2,698.6$ & 100 & 265.0 & 100 & 1.6 & 100 \\
\hline
\end{tabular}

Table 3. Summary of the Biodiversity Data and Corresponding Values.

\begin{tabular}{|l|l|}
\hline Summary & Biodiversity Data and Values (Approx ) \\
\hline Number of trees: & $563,500,000$ \\
\hline Tree Cover & $63.0 \%$ \\
\hline Most common species of trees: & $\begin{array}{l}\text { Adenaria floribunda, Crack willow, Huon Pine } \\
\text { connoted species. }\end{array}$ \\
\hline $\begin{array}{l}\text { Percentage of trees less than 6" (15.2 cm) } \\
\text { diameter }\end{array}$ & $13.3 \%$ \\
\hline Pollution Removal & N/A - data not collected \\
\hline Carbon Storage & 519.4 million metric tons ( $\$ 40.1$ trillion) \\
\hline Carbon Sequestration & 10.44 million metric tons ( $\$ 806$ billion/year) \\
\hline Oxygen Production & 12.6 million metric tons/year \\
\hline Avoided Runoff & 52.5 million cubic meters/year (N50.9 billion/year). \\
\hline
\end{tabular}

\section{Results And Discussion}

It has been revealed that land degradation, abuse, and misuse in the parks are both a part and consequence of environmental changes leading to the loss of valuable biodiversity and land resources. The following findings were reported from the study metadata and report using the i-Tree Eco v6.0.23 from January to September 2018 under the following characteristics: Photosynthetically Active Radiation, Rain/Precipitation, Temperature, Transpiration, Evaporation, water intercepted by trees, Avoided Runoff by trees, Potential Evaporation by trees, Isoprene and Monoterpene by trees.

\subsection{Trees Benefits for Biodiversity Conservation}

This section further discusses the tree benefits of green, low carbon, and sustainable environment within the context of biodiversity conservation considering; Carbon Storage, Carbon Sequestration, Hydrology Effects, Pollution Removal, Oxygen production, and Volatile Organic Compounds (VOCs). 


\subsubsection{Photosynthetically Active Radiation and Precipitation}

The report (Figure 8a) displays the hourly photosynthetically active radiation based on weather data. The precipitation report (Figure $8 \mathrm{~b}$ ) displays the hourly precipitation based on weather data. This report displays results in line chart and table formats for the user-designated weather year.

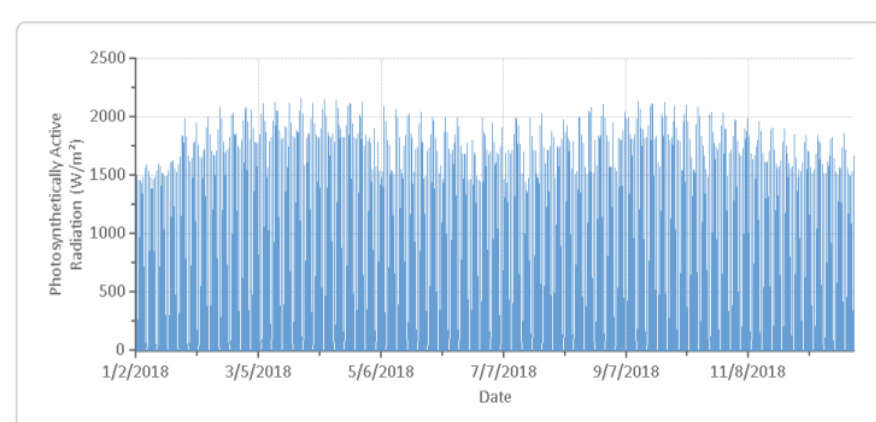

(a)

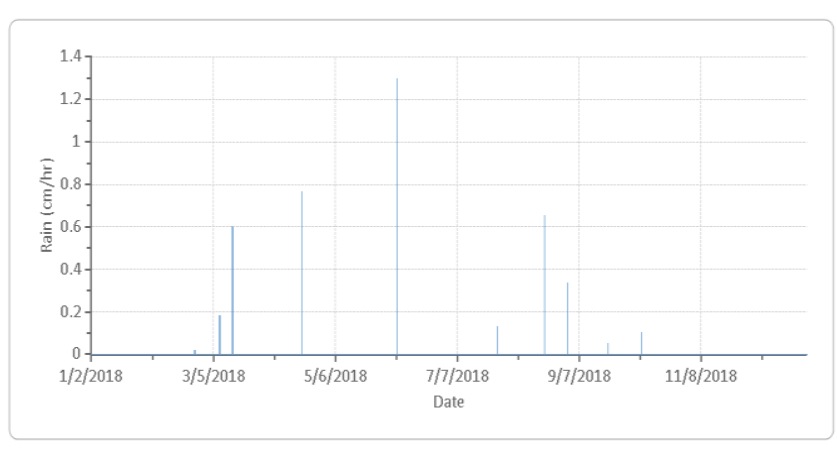

(b)

Figure 8. (a) Photosynthetically Active Radiation. (b) Precipitation.

\subsubsection{Temperature and Transpiration}

The report (Figure 9a) displays hourly air temperature based on the weather data. This report displays results in line chart and table formats for the user-designated weather year. The report (Figure 9b) also displays the hourly transpiration by trees. Transpiration is the amount of water moved through plants and released into the atmosphere.

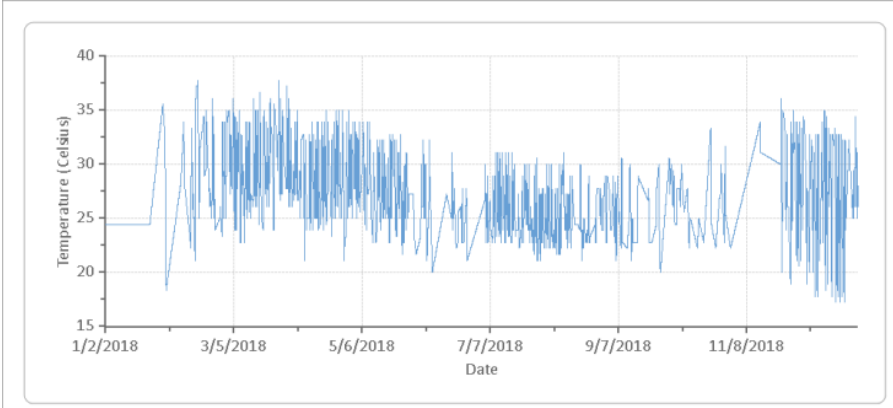

(a)

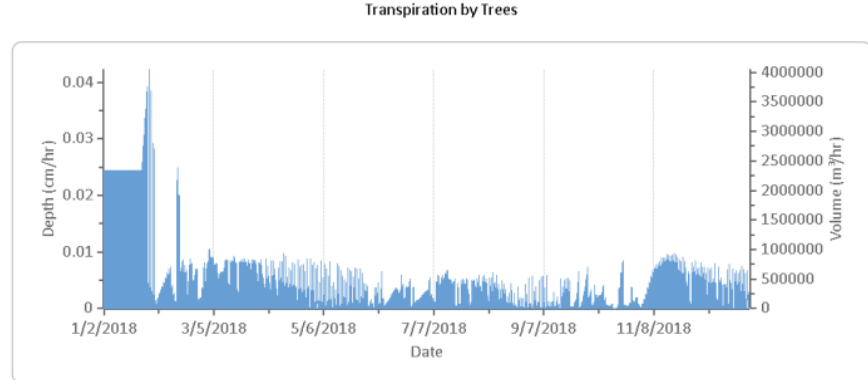

(b)

Figure 9. (a) Temperature. (b) Transpiration.

\subsubsection{Evaporation and Water Intercepted by trees}

The hourly evaporation by trees is shown in the data report (Figure 10a). The amount of water released into the atmosphere from a plant's surface is referred to as evaporation. The hourly water interception by trees is shown in the data report (Figure $10 \mathrm{~b})$. The amount of rainwater that fell on plants and was intercepted by the leaves and stems is referred to as rainwater captured. This water evaporates into the atmosphere eventually. For the user-specified weather year, this report presents results in a line chart and tabular forms 


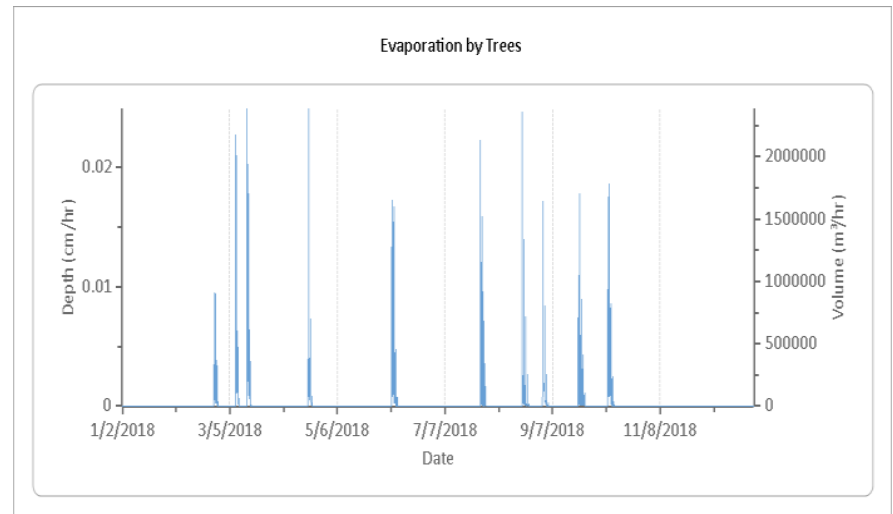

(a)

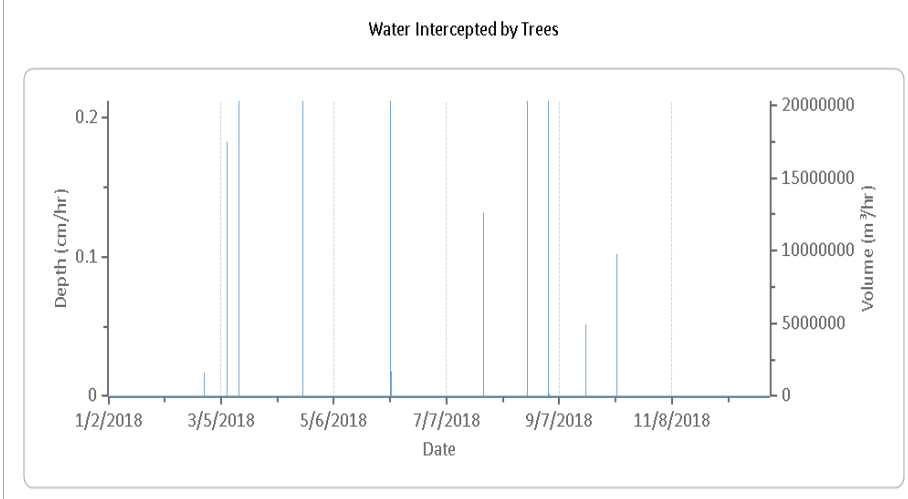

(b)

Figure 10. (a) Evaporation. (b) Water Intercepted by trees.

\subsubsection{Avoided Runoff by trees and Potential Evaporation by trees}

The hourly prevented runoff by trees is shown in the report (Figure 11a). The quantity of water that would otherwise become surface runoff into streams but does not is known as avoided runoff. Water interception by plants, ground depression storage, infiltration on pervious ground covers, and overland flow on impermeable ground covers are all factored into the calculations.

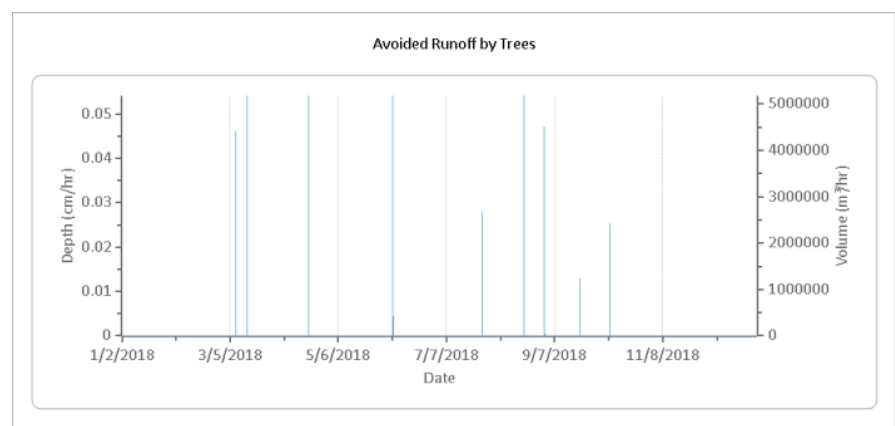

(a)

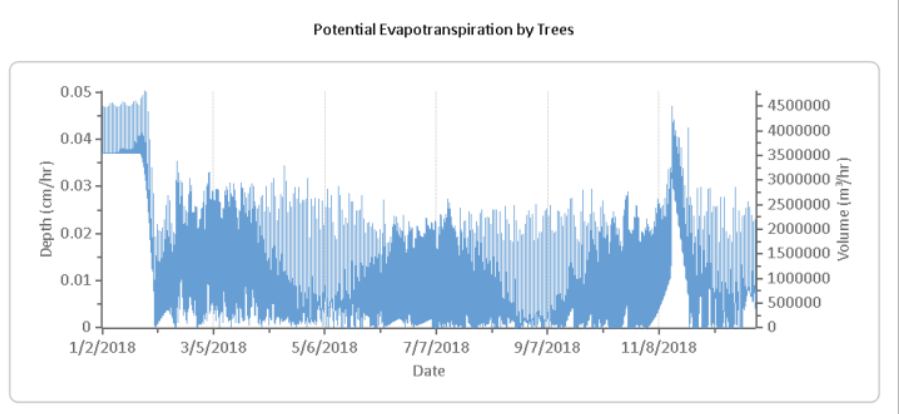

(b)

Figure 11. (a) Avoided Runoff by trees. (b) Potential Evaporation by trees.

The report (Figure 11b) displays the hourly potential evapotranspiration by trees. Potential evapotranspiration is the sum of the evaporation from the soil and the transpiration from plants that would occur if an unlimited amount of water were available.

\subsubsection{Isoprene and Monoterpene by trees}

The report (Figure 12a) displays hourly estimates of the isoprene emissions of all trees in your study area.

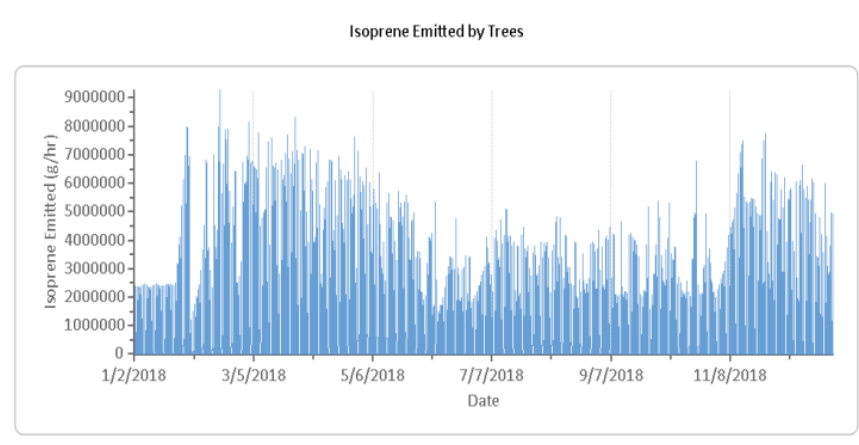

(a)

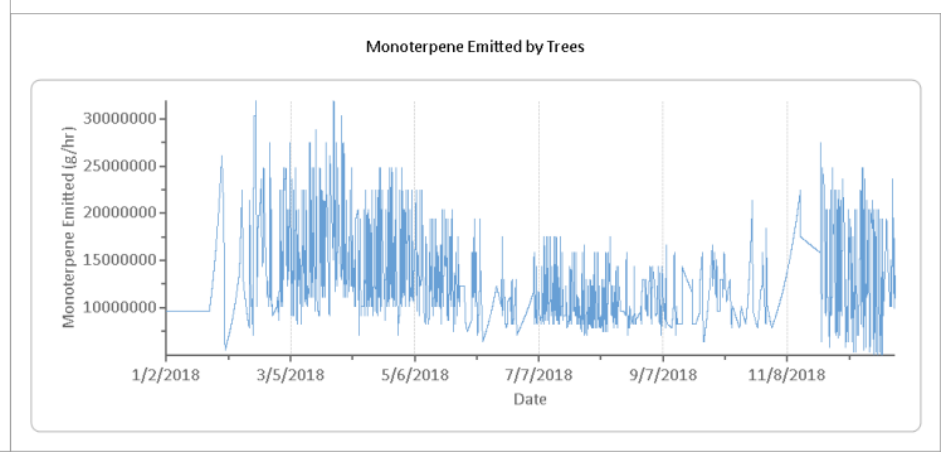

(b)

Figure 12. (a) Isoprene by trees. (b) Monoterpene by trees. 
The report (Figure 12b) also displays hourly estimates of the monoterpene emissions of all trees in your study area. This report displays results in line chart and table formats for the project's available weather data for the year 2018.

\subsection{Tree Characteristics of Kainji National Park}

The protected area of Kainji Park has an estimated 563,500,000 trees with a tree cover of 63.0 percent. The three most common species are Adenaria floribunda (13.3 percent), Crack willow (6.7 percent), and Huon Pine (6.7 percent). The overall tree density is 150 trees/acre. The protected forests are composed of a mix of native and exotic tree species.

As a result, tree diversification in protected forests is generally greater than in adjacent native environments. Increased tree diversity can reduce the overall damage or devastation caused by a species-specific insect or disease, but it can also put native plants in danger if any of the introduced species are invasive and can really and replace native species.

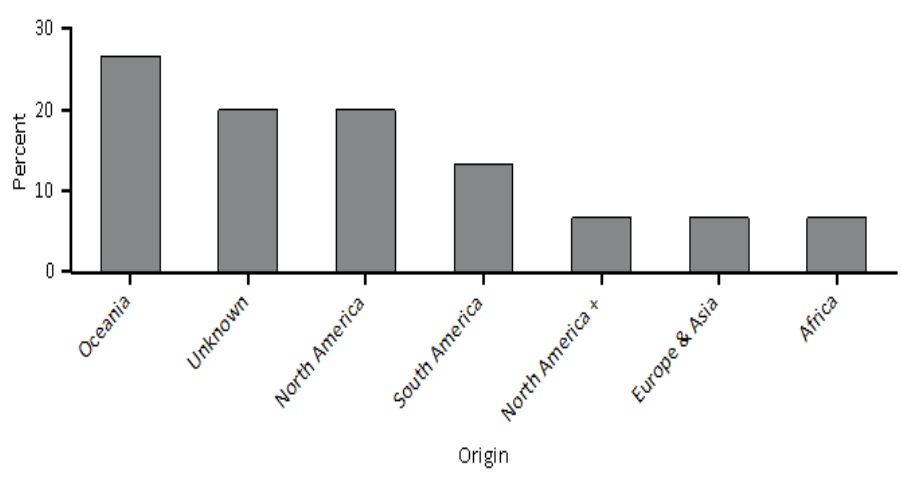

(a)

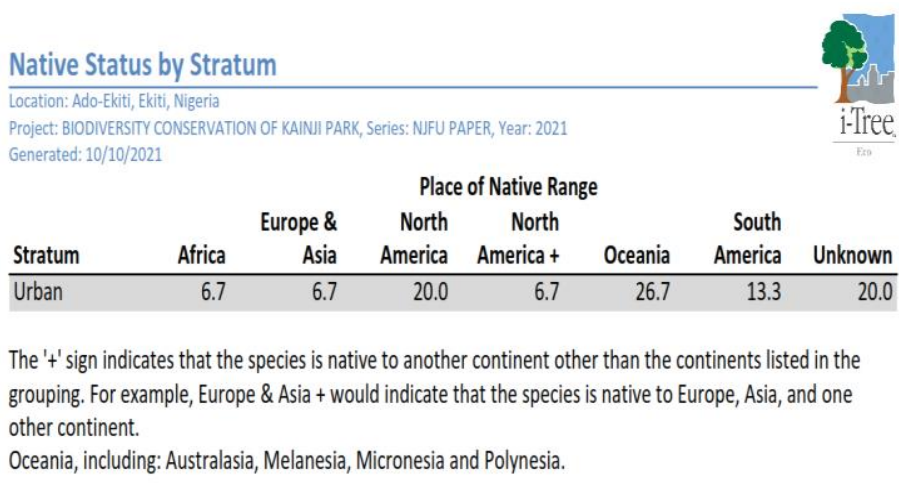

(b)

Figure 13. (a) Chart showing the percentage of live trees population by area of native origin. \& (b) Table showing the percentage of live trees population by area of native origin.

Only around $7 \%$ of the trees are native to Africa, while the majority of the trees originate from Oceania ( 27 percent of the trees). The vitality, ability to adapt, reproductive capacity, and overall absence of natural adversaries are all characteristics of invasive plant species. They can use these characteristics to eliminate native trees, posing a hazard to the ecological regions.

Figure 13 shows estimates of the proportion of each species of tree identified in each Diameter at Breast Height (DBH) size class in the study. The proportion of the tree species population by $\mathrm{DBH}$ class for each of the ten most frequent species in the research region is presented in the chart. 

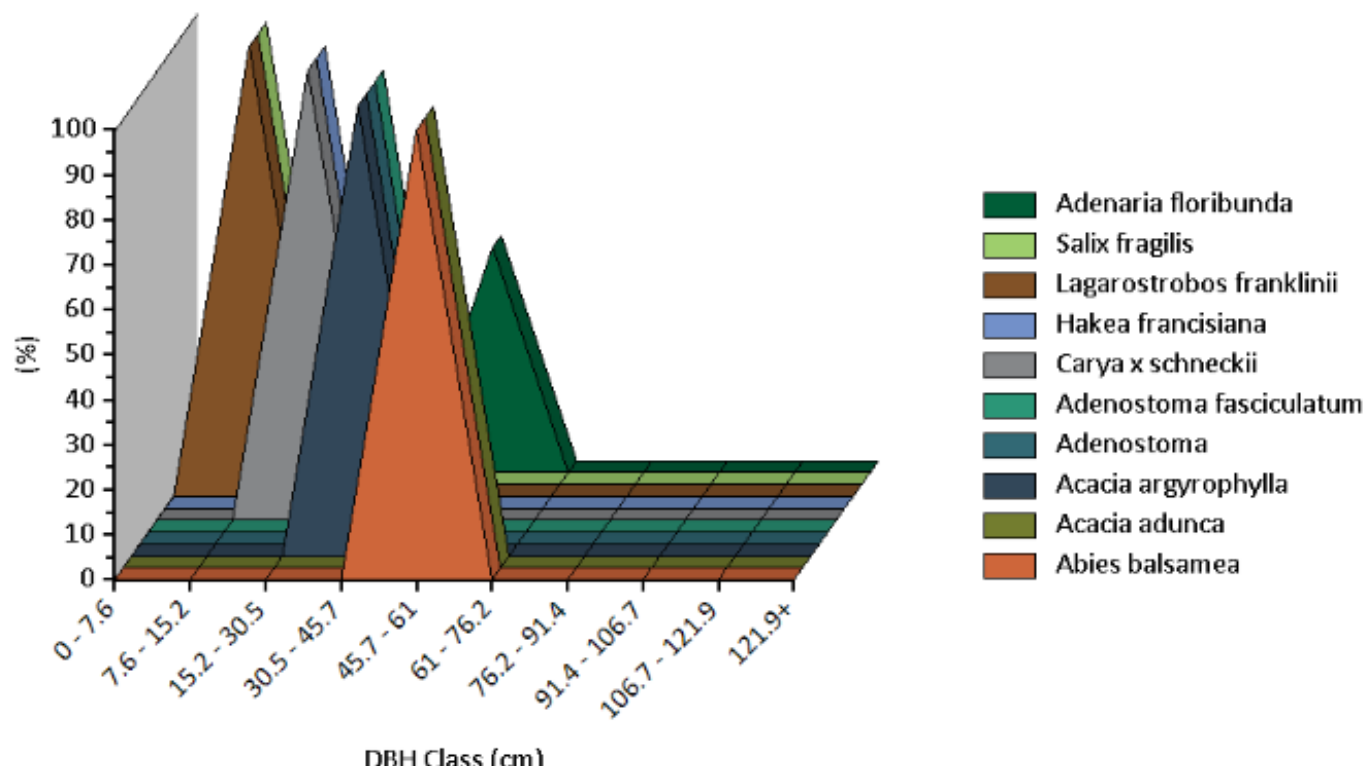

Figure 14. Percentage of Species Distribution by DBH Class.

The report provides total estimates and percentage contributions of the number of trees for each species in the study area. This report displays results in pie charts and table formats below (Figure $15 \mathrm{a} \& \mathrm{~b}$ ).
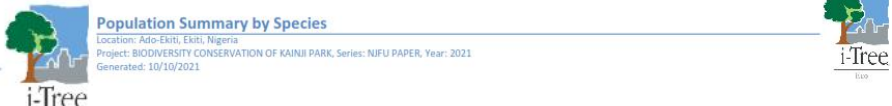

\begin{tabular}{lrr} 
Species & Number of Trees & Percent of Population \\
\hline Adenaria floribunda & $75,128,717$ & $13.3 \%$ \\
Salix fragilis & $37,564,359$ & $6.7 \%$ \\
Lagarostrobos franklinii & $37,564,359$ & $6.7 \%$ \\
Hakea francisiana & $37,564,359$ & $6.7 \%$ \\
Carya x schneckii & $37,564,359$ & $6.7 \%$ \\
Adenostoma fasciculatum & $37,564,359$ & $6.7 \%$ \\
Adenostoma & $37,564,359$ & $6.7 \%$ \\
Acacia argyrophylla & $37,564,359$ & $6.7 \%$ \\
Acacia adunca & $37,564,359$ & $6.7 \%$ \\
Abies balsamea & $37,564,359$ & $6.7 \%$ \\
Dovyalis abyssinica & $37,564,359$ & $6.7 \%$ \\
Abarema & $37,564,359$ & $6.7 \%$ \\
Abelia & $37,564,359$ & $6.7 \%$ \\
Abies & $37,564,359$ & $6.7 \%$ \\
\hline Total & $563,465,378$ & $100 \%$
\end{tabular}

(a)

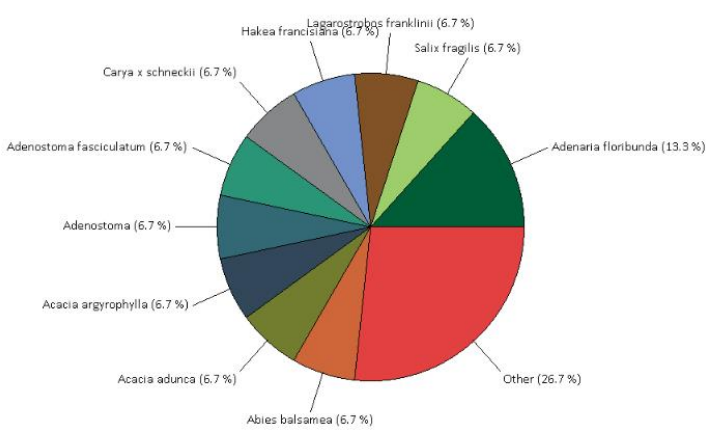

(b)

Figure 15. (a) Tables showing the Population Summary by Species (b) Pie Charts showing the Population Summary by Species

4.2.1 Urban Forest Cover Leaf Area and Importance values

Several plant advantages are proportional to the plant's robust leaf pore volume. Trees cover about 63percent of Kainji National Park protected area and provide 39.14 thousand sqm of leaf area. the most dominant species in terms of leaf area are Abyssinian Gooseberry, fir spp, and abelia spp. 
Table 4. The table shows the 10 species with the greatest importance values.

\begin{tabular}{|lrrr|}
\hline Species Name & $\begin{array}{r}\text { Percent } \\
\text { Population }\end{array}$ & $\begin{array}{r}\text { Percent } \\
\text { Leaf Area }\end{array}$ & IV \\
\hline Abyssinian Gooseberry & 6.7 & 27.0 & 33.7 \\
fir spp & 6.7 & 20.7 & 27.3 \\
abelia spp & 6.7 & 12.4 & 19.0 \\
Adenaria floribunda & 13.3 & 3.6 & 16.9 \\
Balsam fir & 6.7 & 7.7 & 14.4 \\
chamise spp & 6.7 & 6.9 & 13.6 \\
Chamise & 6.7 & 6.6 & 13.2 \\
abarema spp & 6.7 & 6.4 & 13.0 \\
Schneck's hickory & 6.7 & 3.3 & 10.0 \\
Grass-leaf Hakea & 6.7 & 2.7 & 9.4 \\
\hline
\end{tabular}

Importance values (IV) are calculated as the sum of percentage population and percentage leaf area. High importance values do not mean that these trees should necessarily be encouraged in the future; rather these species currently dominate the Kainji National Park forest structure.

\subsubsection{Air Pollution Removal by Urban Trees}

Poor air quality is a problem in many urban areas. It has the potential to negatively impact human health, landscape materials, and ecological processes, as well as reduce visibility. The urban forest can help to improve air quality by decreasing air temperatures, removing pollutants from the air directly, and lowering energy usage in buildings, which reduces power plant air pollution emissions. Dwyer and Nowak [25] argue that trees emit volatile organic compounds that contribute to ozone generation. To estimate pollution clearance by trees in Kainji Park, researchers analyzed field data, present pollution, and meteorological data. The most pollutant eliminated was carbon monoxide. Trees are predicted to remove at least 10,000 tons of ozone (O3), carbon monoxide (CO), nitrogen dioxide (NO2), microscopic particles less than 2.5 microns (PM2.5), including sulfur dioxide (SO2) from the atmosphere per year, with an associated value.

The research area's trees released an estimated 133.1 thousand tons of volatile organic compounds (VOCs) in 2021. (12.45 thousand tons of isoprene and 120.7 thousand tons of monoterpenes). Emissions vary per species, depending on species features (for example, some genera, like oaks, produce a lot of isoprenes) and leaf biomass. Fir spp. and Balsam fir accounted for approximately $80 \%$ of the VOC emissions in the urban forest.

Table 5. The table shows the VOC Emissions by Individual Trees.

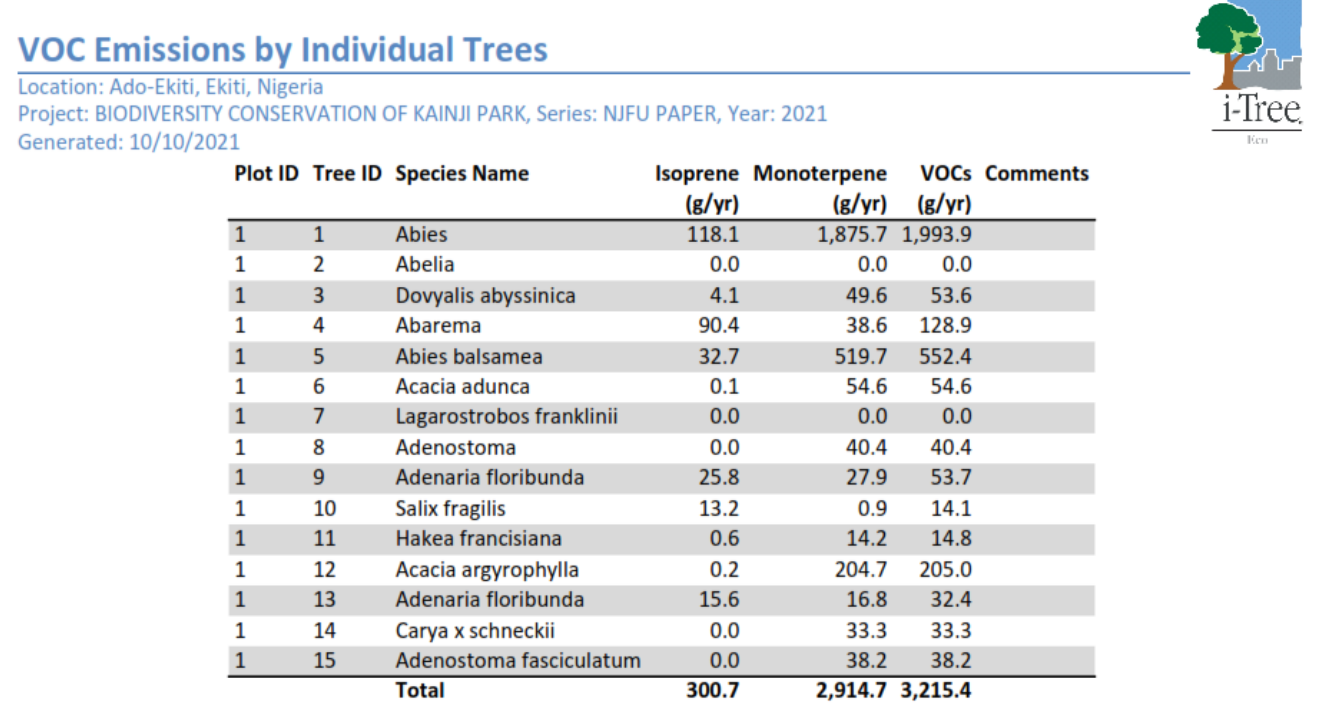


The table seen in the action panel to the right provides total estimates of the VOC (volatile organic compound) emissions of each tree in Kainji National Park. Emissions are displayed for monoterpene, isoprene, and the sum of both.

\subsubsection{Carbon Storage and Sequestration}

Anthropogenic global warming and its ramifications on the environment are important worldwide concerns. Every year, trees trap carbon in new growth, reducing the quantity of carbon in the atmosphere. The size and health of the trees affect the quantity of carbon stored each year. The gross sequestration of Kainji National Park trees is about 11.5 million tons of carbon per year. Net carbon sequestration in the forest is about 5.207 million tons.

Table 6 \& 7. The table shows Carbon Storage and Carbon Sequestration of Individual Trees.

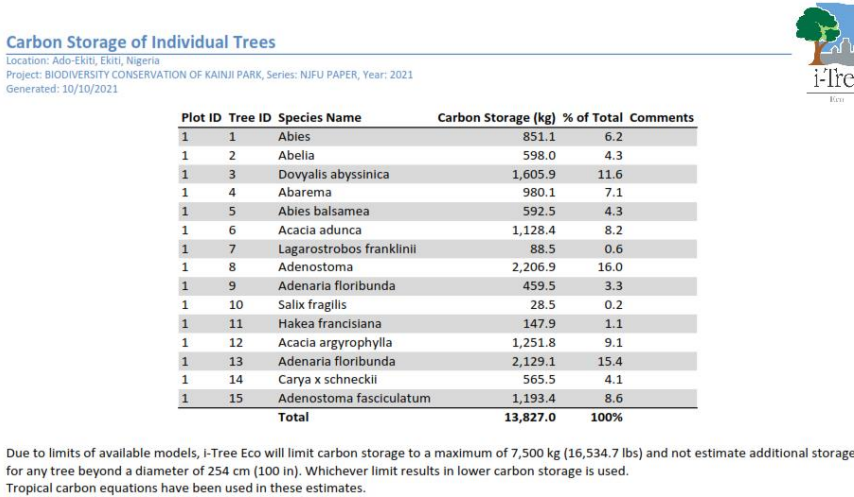

(a)
Carbon Sequestration of Individual

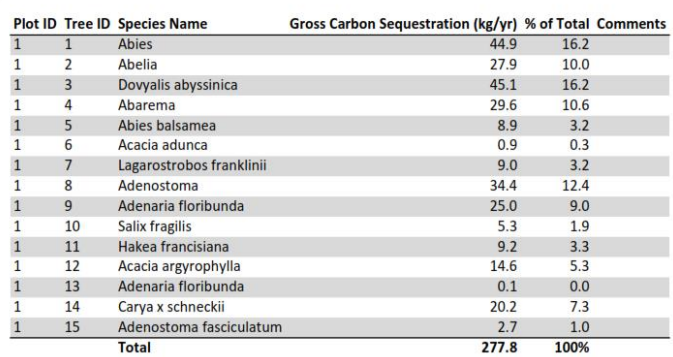

(b)

Table 6 \& 7. (a) The table provides the estimates of carbon storage for each of the trees sampled in Kainji National Park. The percentage contribution to the total carbon storage of all sampled trees is also reported. (b) The table provides estimates of gross carbon sequestration for each of the trees sampled in the study area. The percentage contribution to the total gross carbon sequestration of all sampled trees is also reported.

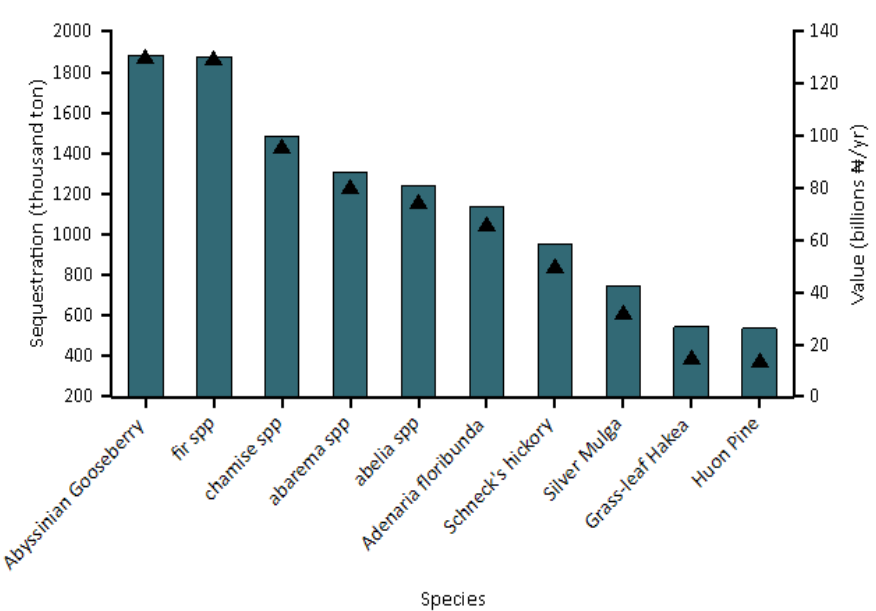

(a)

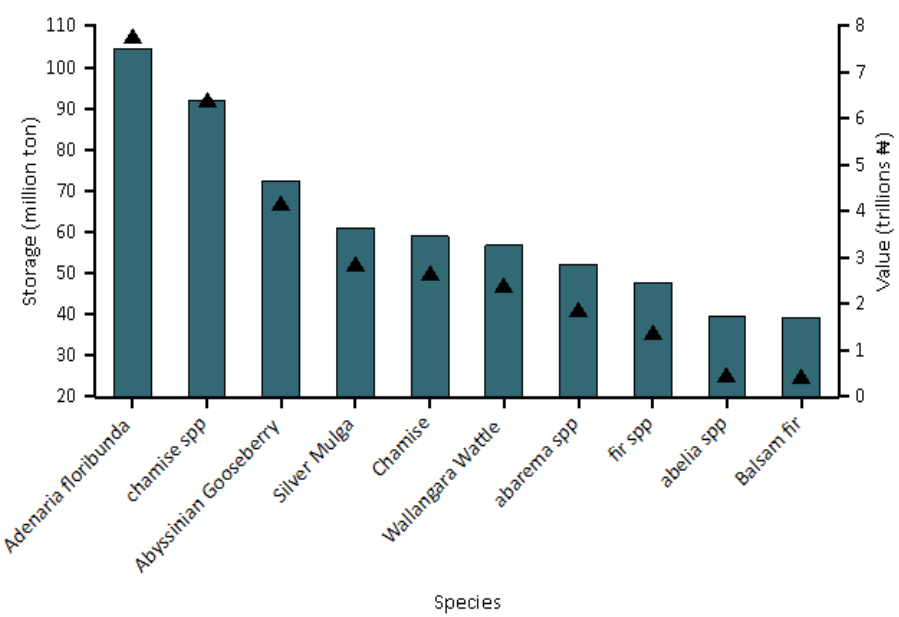

(b)

Figure 16. (a) Estimated annual gross Carbon Sequestration and value for park tree species with the greatest sequestration. (b) Estimated annual gross Carbon Storage and value for park tree species with the greatest storage.

Another method that trees might impact global climate change is through carbon storage [26-29]. A tree stores more carbon as it develops by storing it in its accumulated tissue. When a tree dies and decays, much of the carbon it has stored is released back into the atmosphere. As a result, carbon storage is a measure of how much carbon may also be released if trees are left to die and degrade. When a tree dies, the wood may be used to make long-lasting wood products, heat buildings, or generate electricity, reducing carbon emissions from decomposition or fossil-fuel or wood-based power plants. Kainji National 
Park's trees are believed to contain 573,000,000 tons of carbon (40.1 trillion) in their trunks. Adenaria floribunda stores the most carbon (about $18.7 \%$ of the total carbon stored) and Abyssinian Gooseberry sequesters the most among the species studied (approximately 16.2 percent of all sequestered carbon).

\subsubsection{Oxygen Production}

One of the most widely touted benefits of trees is the creation of oxygen. The quantity of carbon stored by a tree, which is linked to the buildup of tree biomass, is directly proportional to its net yearly oxygen output. The amount of oxygen produced by trees in the research region is estimated to be 13.89 million tons per year. However, because of the vast and relatively consistent amount of oxygen in the atmosphere and massive generation by aquatic systems, this tree benefit is very minor. Most National Parks and Nature-protected places have a large reservoir of oxygen in their atmosphere.

Table 8 \& 9. The table shows Oxygen Production by Trees.

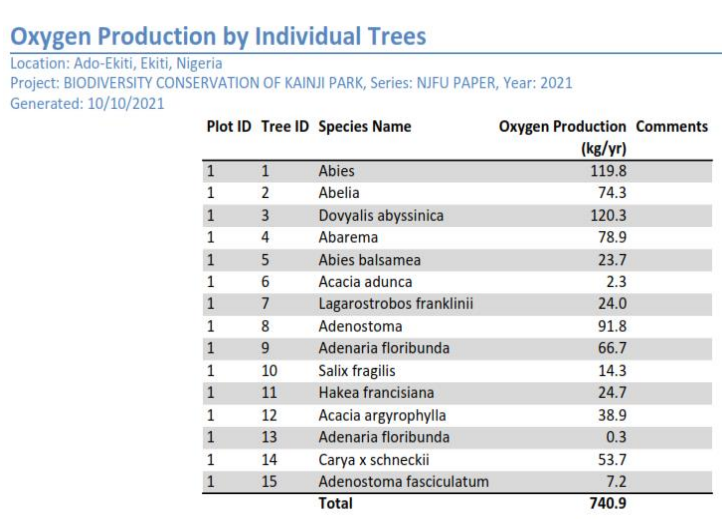

(a)

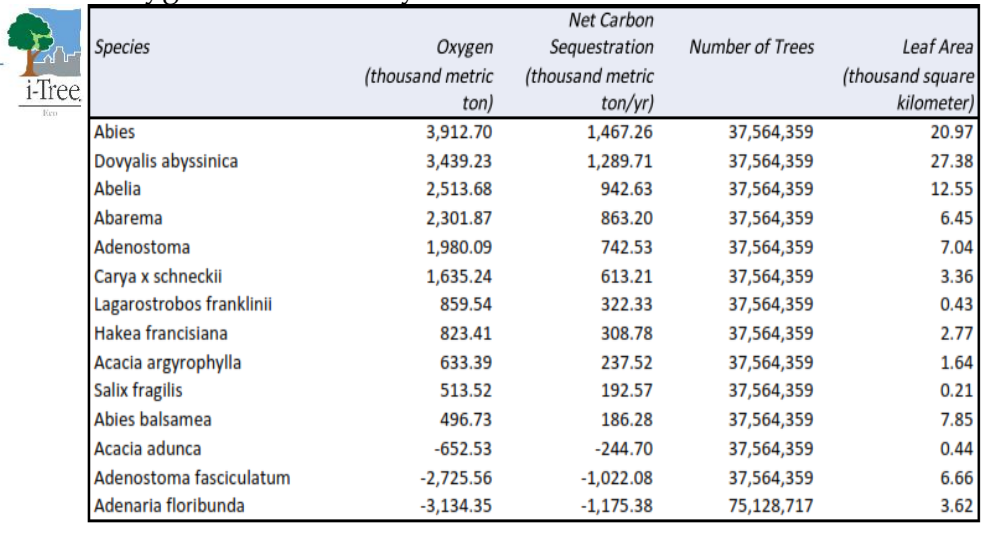

(b)

Table 8 \& 9. (a) The table showing Net Oxygen Production by Individual Trees. (b) The table shows the Number of Trees, the Net Oxygen Production, the Net Carbon Sequestration by Individual Trees and the Leaf Area.

\subsubsection{Avoided Runoff}

Surface water runoff from most protected areas may be a source of pollution in streams, marshes, rivers, lakes, and seas, which is a source of worry in many metropolitan areas [30-32]. During precipitation events, vegetation (trees and bushes) intercepts some of the precipitation, while the rest reaches the ground. The enormous number of impermeable surfaces in metropolitan areas increases the level of stormwater. 


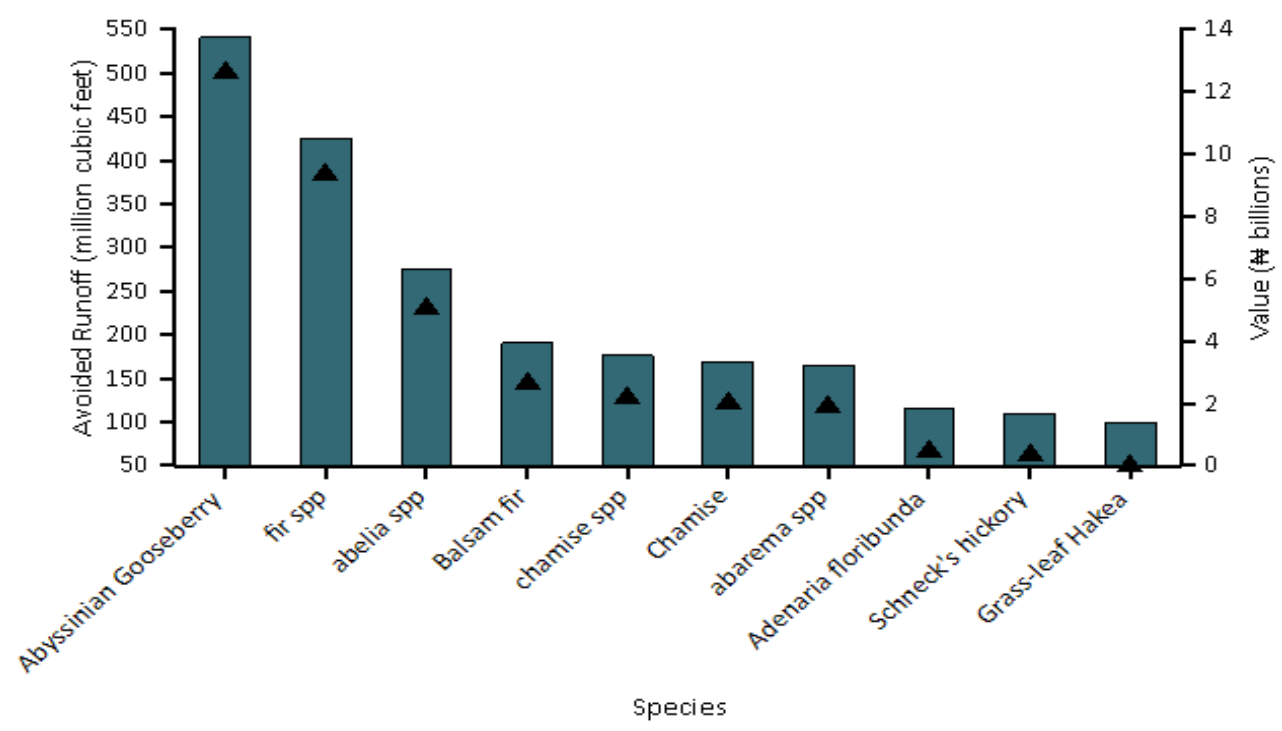

Figure 17. The chart shows the avoided runoff and the value for the species with the greatest overall impact of runoff.

Municipal trees and bushes, on the other hand, help to reduce surface runoff. Trees and bushes collect rainwater, while their root systems aid in absorption and soil retention. The research site's trees and bushes assist to minimize runoff by 1.85 billion cubic meters per year. Local weather from the user-designated weather station is used to estimate avoided runoff. The total yearly precipitation in 2018 was $248.92 \mathrm{~mm}$, according to the statistics gathered.

\section{Conclusions}

This study concludes by stating the need to develop the national parks and nature-protected department and/or forest management committee to help improve biodiversity conservations, forest, and urban air quality. The conservation strategies can come in the form of strict legislation or an increase in the number of healthy flora and fauna. The need to sustain large, healthy trees can not be overemphasized. The usage of fossil fuels to maintain vegetation is being reduced. Experts in conservation must plant trees in energy-saving sites, as well as trees to shade wooded regions. The provision of sufficient water so that the park does not suffer from a long drought or water deficit, which might result in the extinction of trees and species. The elimination of air pollution by urban trees is equally critical in the maintenance of protected forests. According to this study, the areas around national parks should have a high population density and urbanization encroachment since multiple human activities harm the parks. Deforestation, uncontrolled burning, and illegal grazing are among the human effects that are particularly prominent in the Kainji National Park's Zugurma zone. Illegal hunting has resulted in relatively low concentrations of wild animals. Due to the sheer large amount of illicit fishing that takes place in and around the Kainji Lake, the lake's fish farming industry has experienced a significant and incremental loss in the past years.

Remotely-sensed information usually provided a good presentation of national parks and protected areas changing land covers. This can help to achieve biodiversity mapping of the environmental impact analysis. This indicates that future strategies of conserving biodiversity in parks should focus as much on both the community-based participatory approach and the socio-economic dimension of biodiversity conservation but to jettison the scientific study of species and habitats. 
At the national level, there have to be strict government policies against illegal logging of forest wood and non-wood and timber products and illegal poaching activities causing deforestation at all the reserved forest areas and national parks.

Author Contributions: A. J. prepared the introduction, literature review, conceptualization, methodology and writing of the manuscript. T. X. reviewed and revised the manuscript to this present form. A. J. and T. X. have both read and agree to the published version of the manuscript.

Funding: This research received no external funding.

Acknowledgements: The authors express sincere appreciation to the editorial team and reviewers of the MDPI Conservation Journal for reviewing this manuscript.

Conflicts of Interest: "The authors declare no conflict of interest."

\section{References}

1. Conservation International. Retrieved from

https://www.yumpu.com/en/document/view/37491711/annual-report-2008-library-conservation-international (2007).

2. United Nations Environment Programme, World Conservation Monitoring Centre. Kainji Lake National Park". Archived from the original on 30 September 2007. Retrieved 11 May 2012. DOI: 10.9734/arrb/2021/v36i830417.

3. Kapos, Valerie, Werner A. Kurz, Toby Gardner, Joice Ferreira, Manuel Guariguata, Lian Pin Koh, Stephanie Mansourian. "Impacts of forest and land management on biodiversity and carbon." IUFRO World Series Volume 31, p. 53-80. 31 (2012): 53-80. https://www.fs.usda.gov/treesearch/pubs/47890.

4. Eagles, Paul FJ, and Stephen F. McCool. Tourism in national parks and protected areas: Planning and management. Cabi, 2002. Retrieved from https://books.google.com/books, 2021

5. Brown, Jessica, and Brent Mitchell. "Extending the reach of national parks and protected areas: Local stewardship initiatives." In National parks and protected areas, pp. 103-116. Springer, Berlin, Heidelberg, 1997. DOI: 10.1007/978-3-642-60907-7_9.

6. Clerici, Nicola, Camilo Salazar, Carolina Pardo-Díaz, Chris D. Jiggins, James E. Richardson, and Mauricio Linares. "Peace in Colombia is a critical moment for Neotropical connectivity and conservation: Save the northern Andes-Amazon Biodiversity Bridge." Conservation Letters 12, no. 1 (2019): e12594. https://doi.org/10.1111/conl.12594.

7. Mittermeier, Russell A. "Conservation International and biodiversity conservation." Nature 405, no. 6783 (2000): 254-254. DOI: https://doi.org/10.1038/35012266.

8. Mallon, Cyrus A., Franck Poly, Xavier Le Roux, Irene Marring, Jan Dirk van Elsas, and Joana Falcão Salles. "Resource pulses can alleviate the biodiversity-invasion relationship in soil microbial communities." Ecology 96, no. 4 (2015): 915-926. https://doi.org/10.1890/14-1001.1.

9. International Union for Conservation of Nature, International Union for Conservation of Nature, Natural Resources. Species Survival Commission and IUCN Species Survival Commission. IUCN Red List categories and criteria. IUCN, 2001. Retrieved from https://books.google.com/books?.

10. Imarhiagbe, Odoligie, Wisdom Oghenevwogaga Egboduku, and Beluchukwu Joseph Nwankwo. "A review of the biodiversity conservation status of Nigeria." Journal of Wildlife and Biodiversity 4, no. 1 (2020): 73-83. 10.22120/JWB.2019.115501.1096.

11. Akindele, Emmanuel O., Michael C. Ekwemuka, Paul Apeverga, Tajudeen O. Amusa, Samuel Olajuyigbe, Oluwakayode M. Coker, Fatsuma Olaleru et al. "Assessing awareness on biodiversity conservation among Nigerians: the Aichi Biodiversity Target 1." Biodiversity and Conservation 30, no. 7 (2021): 1947-1970. DOI: https://doi.org/10.1007/s10531-021-02175-x.

12. Radić, Boris, and Suzana Gavrilovic. "Natural Habitat Loss: Causes and Implications of Structural and Functional Changes." Life on Land (2021): 699-712. DOI: https://doi.org/10.1007/978-3-319-95981-8_6.

13. Mukherjee, Sudeshna. "Globalisation and the political economy of protected areas." Globalisation, Environment and Social Justice. Routledge India, 2018. 109-129. https://www.taylorfrancis.com/chapters/edit/10.4324/9780429455766-5/ globalisation-political-economy-protected-areas-sudeshna-mukherjee.

14. Day, Jon, Nigel Dudley, Marc Hockings, Glen Holmes, Dan d'A. Laffoley, Sue Stolton, and Susan M. Wells. Guidelines for applying the IUCN protected area management categories to marine protected areas. IUCN, 2012. http://dx.doi.org/10.25607/OBP-694.

15. Ortiz, María José. "Aichi biodiversity targets on direct and indirect drivers of biodiversity loss." Environmental Law Review 13, no. 2 (2011): 100-106. https://doi.org/10.1350/enlr.2011.13.2.121.

16. Newbold, Tim, Georgina L. Adams, Gonzalo Albaladejo Robles, Elizabeth H. Boakes, Guilherme Braga Ferreira, Abbie SA Chapman, Adrienne Etard et al. "Climate and land-use change homogenise terrestrial biodiversity, with consequences for ecosystem functioning and human well-being." Emerging Topics in Life Sciences 3, no. 2 (2019): 207-219. https://doi.org/10.1042/ETLS20180135.

17. Essl, Franz, Guillaume Latombe, Bernd Lenzner, Shyama Pagad, Hanno Seebens, Kevin Smith, John RU Wilson, and Piero Genovesi. "The Convention on Biological Diversity (CBD)'s Post-2020 target on invasive alien species-what should it include and how should it be monitored?." NeoBiota 62 (2020): 99. https://neobiota.pensoft.net/article/53972/download/pdf/ 
18. Morgera, Elisa. "Dawn of a New Day: The Evolving Relationship between the Convention on Biological Diversity and International Human Rights Law." Wake Forest $\quad$ L. $\quad$ Rev. 53 (2018): https://heinonline.org/hol-cgi-bin/get_pdf.cgi?handle=hein.journals/wflr53\&section=30.

19. Prip, Christian. "The Convention on Biological Diversity as a legal framework for safeguarding ecosystem services." Ecosystem Services 29 (2018): 199-204. https://doi.org/10.1016/j.ecoser.2017.02.015.

20. Opoku, Alex. "Biodiversity and the built environment: Implications for the Sustainable Development Goals (SDGs)." Resources, conservation and recycling 141 (2019): 1-7. https://doi.org/10.1016/j.resconrec.2018.10.011.

21. Osunsina, I. O. O., J. Osunsina, O. O. Oduntan, Y. Oladiran, and O. T. Moyaki. "Awareness and perception of climate change and variability among indigenous people living around Nigerian national parks." African Journal of Agriculture Technology and Environment Vol 8, no. 1 (2019): 47-61. https://www.researchgate.net/profile/Israel-Osunsina/publication/.pdf.

22. Elijah, Elizabeth, Vincent N. Ojeh, Anita H. Philip, M. Maaku Joshua, and Gabriel Bonchak. "Land Transformation of Tropical Forest Conservation of Gashaka-Gumti National Park, Nigeria from 1987-2014." Asian Journal of Environment E Ecology (2019): 1-17.https://www.researchgate.net/publication/332975202_Land_Transformation_of_Tropical_Forest_Conservation_of_Gasha ka-Gumti_National_Park_Nigeria_from_1987-2014.

23. Brankov, Jovana, Tamara Jojić Glavonjić, Ana Milanović Pešić, Marko D. Petrović, and Tatiana N. Tretiakova. "Residents' perceptions of tourism impact on community in national parks in Serbia." European countryside 11, no. 1 (2019): 124-142. https://www.researchgate.net/publication/332456114_Residents'_Perceptions_of_Tourism_Impact_on_Community_in_Nation al_Parks_in_Serbia.

24. Convention on Biological Diversity Secretariat of the Convention on Biological Diversity (2007). Year in Review 2006. Montreal. Retrieved from https://www.cbd.int/doc/reports/cbd-report-2006-en.pdf. (2007).

25. Dwyer, John F., and David J. Nowak. "A national assessment of the urban forest: An overview." In Society of American Foresters 1999 National Convention Portland, Oregon. $\quad$ p. 2000. https://www.researchgate.net/publication/279562620_Sustaining_urban_forests.

26. Rana, Krishna, Munesh Kumar, and Amit Kumar. "Assessment of annual shoot biomass and carbon storage potential of Grewia optiva: An approach to combat climate change in Garhwal Himalaya." Water, Air, E Soil Pollution 231, no. 9 (2020): 1-13. https://doi.org/10.1007/s11270-020-04825-2.

27. Nunes, Leonel JR, Catarina IR Meireles, Carlos J. Pinto Gomes, and Nuno Almeida Ribeiro. "Forest contribution to climate change mitigation: Management oriented to carbon capture and storage." Climate 8, no. 2 (2020): 21. https://doi.org/10.3390/cli8020021.

28. Tschora, Héloïse, and Francesco Cherubini. "Co-benefits and trade-offs of agroforestry for climate change mitigation and other sustainability goals in West Africa." Global Ecology and Conservation 22 (2020): e00919. https://doi.org/10.1016/j.gecco.2020.e00919.

29. Goodwin, Marissa J., Malcolm P. North, Harold SJ Zald, and Matthew D. Hurteau. "Changing climate reallocates the carbon debt of frequent-fire forests." Global Change Biology 26, no. 11 (2020): 6180-6189. https://doi.org/10.1111/gcb.15318.

30. Jovanelly, T. J., L. Rodríguez-Montero, R. Sánchez-Gutiérrez, L. Mena-Rivera, and D. Thomas. "Evaluating watershed health in Costa Rican national parks and protected areas." Sustainable Water Resources Management 6, no. 5 (2020): 1-14. https://doi.org/10.1007/s40899-020-00431-6.

31. Abd-Elaty, Ismail, Alban Kuriqi, and Abeer El Shahawy. "Environmental rethinking of wastewater drains to manage environmental pollution and alleviate water scarcity." Natural Hazards (2021): 1-28. https://doi.org/10.1007/s11069-021-05040-w.

32. Sikdar, Pradip K. "Environmental Management: Issues and Concerns." Environmental Management: Issues and Concerns in Developing Countries (2021): 1-21. DOI: 10.1007/978-3-030-62529-0_1. 